\title{
Cellular immunity to possible synovial antigens in rheumatoid arthritis
}

\author{
ANDREW D. ROBINSON AND KENNETH D. MUIRDEN \\ From the University of Melbourne, Department of Medicine, Royal Melbourne Hospital, Melbourne, Victoria \\ 3050, Australia
}

SUMMARY A reaction has been demonstrated between extracts of synovial cells removed from intact rheumatoid knee joints and autologous leucocytes. The cell mediated immunity test system used was leucocyte migration inhibition. Variable reactions were found with a spectrum of allogeneic extracts when donor leucocytes came from married or transfused females or transfused males. Leucocytes from healthy (nontransfused) males showed no reaction with any of the extracts. As a period of cell culture was used prior to preparation of this extract to remove nonspecific inhibitory substances, native immunoglobulins, and complexes, the data are best explained by the presence of a foreign pathogen or altered cell component in the synovial cells of these rheumatoid patients.

The pathology of the rheumatoid (RA) joint and particularly the appearance of the synovial membrane suggest that an immune response to persisting antigenic material is involved. Attempts directly to demonstrate a foreign antigen in various components of the joint have been conspicuously unsuccessful (for review see Marmion ${ }^{1}$. By a different approach cell mediated immune techniques have been widely utilised in which studies measure the reactivity of RA peripheral lymphocytes to joint components frequently derived from synovial cultures. Here also attempts to confirm early promising results, for example, of Bacon et al., ${ }^{2} 3$ Kinsella, ${ }^{4}$ and Person and Sharp, ${ }^{5}$ have been generally unsuccessful. ${ }^{6} 7$

In the examples listed crude extracts or explant cultures of synovial membranes derived from surgical procedures were used as a source of potential antigen containing cells to react with autologous and allogeneic leucocytes. In this study the unique method of Fraser and Catt ${ }^{8}$ for isolating and culturing synovial lining cells from intact knee joints has been the source of extracts to study cell mediated immune responses.

\section{Materials and methods}

TEST SUBJECTS

The 10 RA patients used in this study (Table 1) fulfilled the American Rheumatism Association

Accepted for publication 9 November 1979

Correspondence to Dr K. D. Muirden.
Table 1 Leucocyte test subjects

\begin{tabular}{|c|c|c|c|c|c|}
\hline $\begin{array}{l}\text { Case } \\
\text { no. }\end{array}$ & $\begin{array}{l}\text { Agel } \\
\text { Sex }\end{array}$ & $\begin{array}{l}\text { Disease } \\
\text { duration } \\
\text { (years) }\end{array}$ & $\begin{array}{l}\text { Rheu- } \\
\text { matoid } \\
\text { factor }\end{array}$ & $\begin{array}{l}\text { Trans- } \\
\text { fused or } \\
\text { parous }\end{array}$ & Medication \\
\hline \multicolumn{6}{|l|}{$\begin{array}{l}R A \\
\text { patients }\end{array}$} \\
\hline 1 & $56 / \mathrm{M}$ & 3 & + & - & $\begin{array}{l}\text { Indomethacin, } \\
\text { gold }\end{array}$ \\
\hline 2 & $65 / M$ & 2 & + & 一 & $\begin{array}{l}\text { Indomethacin, } \\
\text { naproxen }\end{array}$ \\
\hline 3 & $24 / M$ & 10 & - & - & Indomethacin \\
\hline 4 & $50 / \mathrm{M}$ & 1 & - & + & $\begin{array}{l}\text { Aspirin, } \\
\text { indomethacin } \\
\text { D-penicillamine }\end{array}$ \\
\hline 5 & $55 / \mathrm{M}$ & 5 & + & + & $\begin{array}{l}\text { Aspirin, } \\
\text { ibuprofen } \\
\text { prednisolone } \\
(5 \mathrm{mg})\end{array}$ \\
\hline 6 & $60 / F$ & 16 & + & + & $\begin{array}{l}\text { Aspirin, } \\
\text { naproxen }\end{array}$ \\
\hline 7 & $39 / \mathrm{F}$ & 8 & + & + & $\begin{array}{l}\text { Aspirin, } \\
\text { naproxen }\end{array}$ \\
\hline 8 & $68 / F$ & 3 & + & + & $\begin{array}{l}\text { Aspirin, } \\
\text { indomethacin }\end{array}$ \\
\hline 9 & $56 / \mathrm{F}$ & 6 & - & + & $\begin{array}{l}\text { Ibuprofen, } \\
\text { gold }\end{array}$ \\
\hline 10 & $30 / F$ & 7 & + & + & $\begin{array}{l}\text { Aspirin, } \\
\text { indomethacin, } \\
\text { prednisolone } \\
(3 \mathrm{mg}) \\
\text { D-penicillamine }\end{array}$ \\
\hline \multicolumn{6}{|l|}{$\begin{array}{l}\text { Normal } \\
\text { controls }\end{array}$} \\
\hline $1-10$ & $\begin{array}{l}\text { All } \\
\text { male } \\
24-62 \\
\text { (mean } \\
39)\end{array}$ & 0 & - & - & $\mathrm{Nil}$ \\
\hline
\end{tabular}

criteria for definite or classical rheumatoid arthritis. Control subjects were 10 normal healthy adult males who had not received blood transfusions. This 
control group was chosen to eliminate the possibility of leucocyte inhibition being caused by prior sensitisation of the lymphocytes to transplantation antigens from transfused blood, sperm, or fetal cells.

\section{SOURCE OF SYNOVIAL CELLS}

The synovial cell extracts used as the antigen preparation were obtained by trypsinisation of intact normal (cadaver) knee joints ${ }^{8}$ and rheumatoid knee joints. ${ }^{9}$ The cells were cultured in Eagle's basal media containing $10 \%$ fetal calf serum and $10 \%$ human serum for at least 6 days. All RA cells were used in the primary phase, while controls had a mean passage level of 7 . The highest subculture number was 13 . Only young cultures were used to minimise the effects of long-term culture and passage. ${ }^{10} 11$

PREPARATION OF SYNOVIAL CELL EXTRACTS Because of reports that rheumatoid leucocyte migration may be inhibited by human immunoglobulinIgG or aggregated IgG $^{12-14}$ both $\mathrm{RA}$ and normal cell cultures were carefully treated to eliminate any free or surface bound immunoglobulins (Table 2). All cultures while still in monolayer form were washed in Hanks's balanced salt solution (HBSS) and for 24 hours placed in media containing $10 \%$ fetal calf instead of human serum. This process was repeated for a further 24 hours, and the cells were then washed again with HBSS and scraped off with a rubber spatula. Cell pellets were washed 3 times with HBSS before being disrupted by freeze/ thawing and sonication in $0.5 \mathrm{M}$ sodium chloride in phosphate buffered saline. After centrifugation

\section{Table 2 Preparation of synovial cell extracts}

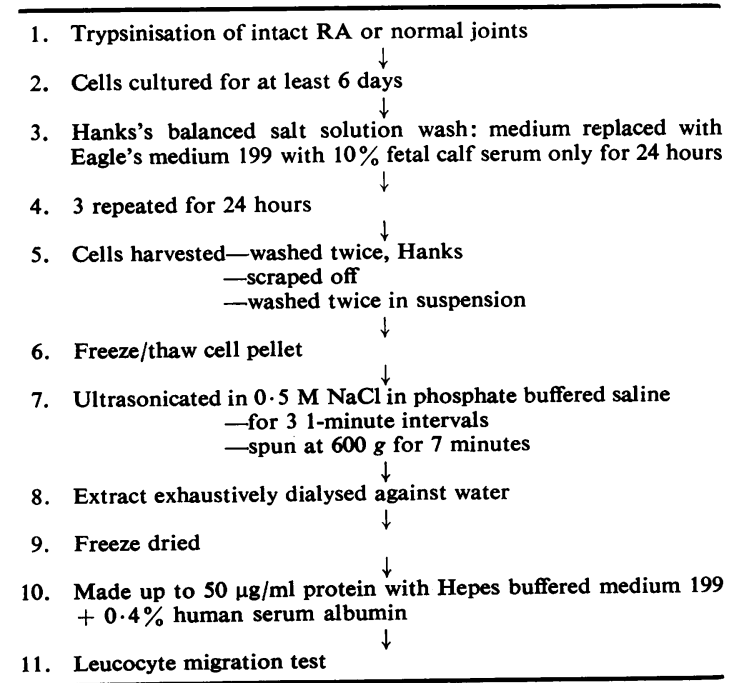

at $600 \mathrm{~g}$ for 7 minutes the extract was then exhaustively dialysed for 3 days against distilled water before being freeze dried. Usually only 200-600 $\mu \mathrm{g}$ of extract was obtained from any one patient. Immediately before use the extract was made up to $50 \mu \mathrm{g} / \mathrm{ml}$ protein with medium 199, containing $20 \mathrm{mM}$ HEPES (Sigma Chemical Company), 100 units per $\mathrm{ml}$ sodium penicillin $\mathrm{G}$, and $100 \mu \mathrm{g}$ per $\mathrm{ml}$ streptomycin sulphate. Glucose, glutamine, and human serum albumin were added to a final concentration of $11 \cdot 1 \mathrm{mM}, 2 \cdot 7 \mathrm{mM}$, and $0.4 \%$ respectively (Table 2). Random cell suspensions were tested for the presence of human immunoglobulin by immunofluorescence with polyvalent antisera (Wellcome Reagents Ltd., Beckenham, England). No immunoglobulin was seen. Synovial cells which had been cultured in human serum were used as a positive control.

\section{CELL MIGRATION INHIBITION}

TESTS

A modification of the leucocyte migration test of Soborg and Bendixon ${ }^{15}^{16}$ was used to assess cellular immunity to the extracts. The erythrocytes were sedimented in heparinised blood from patients or controls with $6 \%$ dextran 150 in normal saline ( $1 \mathrm{ml}$ per $5 \mathrm{ml}$ of whole blood) for $30 \mathrm{~min}$ at $37^{\circ} \mathrm{C}$. Leucocyte-rich plasma was removed, centrifuged to remove platelets, then the cells were washed twice and resuspended in HEPES buffered medium 199 before being packed into $25 \mu \mathrm{l}$ capillary tubes (Microcaps, Drummond), which were sealed at one end with Seal-Ease (Clay Adams). These tubes containing the migrating cells were placed in chambers of $0.5 \mathrm{ml}$ volume (Sterilin plates) containing either medium alone or medium with synovial extract. After 24 hours at $37^{\circ} \mathrm{C}$ the areas of migration were measured by paper planimetry. Each test was run in triplicate for each extract and the mean taken as the final result. Standard deviation was less than $10 \%$. The leucocytes of RA patients were tested against at least 3 extractstheir own autologous extract, an allogeneic RA extract, and control synovial cell extract. Control subjects could be tested against allogeneic extracts only. The degree of migration was expressed as a percentage comparison with the migration area without extract. A migration of $80 \%$ or less was considered as positive inhibition and between 80 and $85 \%$ as probable. Statistical comparison of mean migration percentages was carried out by the Student's $t$ test.

Lymphocytes from both controls and RA patients were separated from whole blood on IsopaqueFicoll gradients (Ficoll-Paque Pharmacia Uppsala, Sweden) and tested for blastogenic response to the 
synovial cell extracts (method of Kinsella ${ }^{4}$. High concentrations of extract caused nonspecific inhibition of lymphocyte growth, and the maximum concentration that could be used was $12 \cdot 5 \mu \mathrm{g} / \mathrm{ml}$. By comparison the concentration used for migration inhibition tests was $50 \mu \mathrm{g} / \mathrm{ml}$ (see below). At this level no blastogenic response was seen in either RA or normal lymphocytes with any of the extracts. Positive controls were included containing $10 \mu \mathrm{g} / \mathrm{ml}$ of conconavalin-A, and these showed stimulation indicies of between 7 and 30 . The failure of this test could be related to the low level of extract required to avoid nonspecific effects. A more purified extract at a high concentration may in the future yield more definite results.

\section{Results}

The optimum extract concentration to induce migration inhibition was first determined by testing leucocytes from 2 control subjects and one RA patient against multiple dilutions of 4 extracts from both RA and normal cells. Strong nonspecific inhibition occurred at high extract concentrations. The highest concentration that did not cause nonspecific inhibition was $50 \mu \mathrm{g} / \mathrm{ml}$, and this level was used throughout these experiments.

The leucocytes from 10 RA patients were tested for reactivity against autologous extracts. Significant inhibition occurred in nine (Fig. 1). The same leucocytes were also tested against other RA extracts and normal cell extracts. Nine of the 34 tests reacted with migrations of $80 \%$ or less and 6 with migrations in the range of $80-85 \%$. No clear correlation was seen between reactions and the presence of rheumatoid factor. Of the 3 seronegative patients 1 failed to react to any extract, 1 reacted to autologous RA extract, and 1 allogeneic control extract, while the third reacted to autologous RA extract, and 1 allogeneic RA extract. The leucocytes of male RA patients who had not received a blood transfusion reacted only against autologous extracts and failed to react against either RA or normal allogeneic extracts. All of the 7 transfused male and transfused or multiparous female patients showed reactions against 1 or more of the allogeneic extracts. Leucocytes from the control group of normal, healthy nontransfused males showed no significant reaction to any of the control or RA extracts. Mean migration percentages are recorded in Table 3.

In two patients it was possible to test extracts of synovial cells removed by different wash-out procedures separated by several months. The consistency of the response was shown in both, as with case 1 an $80 \%$ migration resulted with the 2 extracts, and in case 8 the migration was $80 \%, 77 \%$, and $80 \%$ for the 3 separate extracts.

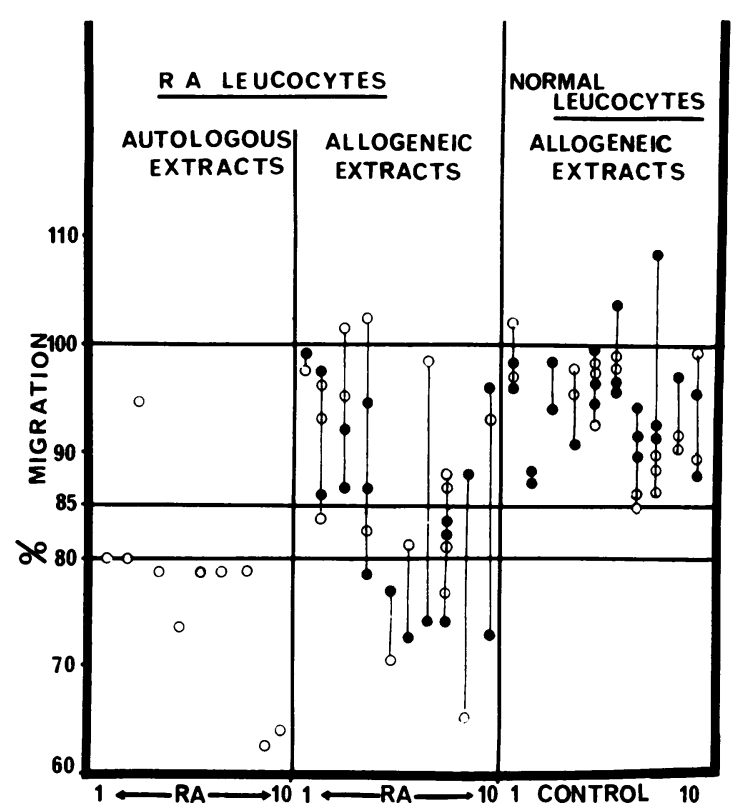

Fig. 1 Leucocyte migration tests in normal control subjects and $R A$ patients. Each vertical row represents the tests performed on 1 individual. The first three $R A$ cases represent the nontransfused male patients.

- extract of normal synovial cells; O extract of $R A$ synovial cells

Table 3 Mean migration percentages

\begin{tabular}{llll}
\hline $\begin{array}{l}\text { Leucocyte } \\
\text { source }\end{array}$ & Extract source & Mean $\pm S D$ & $\begin{array}{l}\text { No. of } \\
\text { tests }\end{array}$ \\
\hline RA & Autologous RA & $77 \cdot 1 \pm 8 \cdot 8$ & 10 \\
RA & Allogeneic normal & $85 \cdot 1 \pm 8 \cdot 5$ & 17 \\
RA & Allogeneic RA & $87 \cdot 7 \pm 10 \cdot 3$ & 17 \\
Control & Allogeneic normal & $95 \cdot 2 \pm 5 \cdot 2$ & 22 \\
Control & Allogeneic RA & $93 \cdot 7 \pm 5 \cdot 1$ & 18 \\
\hline
\end{tabular}

Statistical comparison of the mean migration percentages show no significant difference between the reaction of RA leucocytes with allogeneic RA extracts and with allogeneic control extracts $(P>0.05)$. Similarly, normal leucocytes failed to distinguish between allogeneic normal and RA extracts $(P>0.05)$. The mean migration percentage for the reaction of RA leucocytes with autologous RA extracts was significantly different from that of the same leucocytes with allogeneic RA extracts $(P<0.02)$. It was also significantly different from the mean percentage migration of normal leucocytes with allogeneic $R A$ extracts $(P<0 \cdot 001)$. The reaction of RA or normal leucocytes with allogeneic RA extracts was also significantly different $(P<0.05)$.

Three healthy multiparous females were tested 
against 3 or more control or RA cell extracts. All had leucocytes which reacted to at least 1 allogeneic extract.

\section{Discussion}

The demonstration that 9 out of 10 RA patients in this series possess sensitised lymphocytes to extracts of their own synovial tissue is best explained by the presence of a 'rheumatoid' specific antigen or altered cell component in synovial cells. The 1 patient who did not react was a 24-year-old male patient with a juvenile onset seronegative, HLA B27 positive, polyarthritis with a normal lumbar spine and sacroiliac joints (case 3). As well as reactions to autologous extracts 7 of the 10 patients also showed leucocyte reactions to extracts from allogeneic, normal, or RA synovial membrane. Such reactions may be explained by presensitisation of the patient to transplantation antigens. Immunisation could have occurred from transfused blood, fetal cells, or even from sperm. Cases 1 to 3, which were of nontransfused males, did not respond to a variety of allogeneic extracts. It is clear that sensitisation of human lymphocytes will develop to allogeneic HLA antigens when skin or renal allografts are present. ${ }^{17} 18$

When studying maternal cell mediated immunity to fetal HLA antigens Tait et al..$^{19}$ found that $14 \%$ of parous women gave positive and $21 \%$ doubtful leucocyte migration tests against their fetal lymphocyte preparations. This work has been extended ${ }^{20}$ to testing both parous and nulliparous women for antigen present on their husband's lymphocytes. Over $50 \%$ of the normal married female population appears to be sensitised, and it has been suggested that sperm cells could be the cause of this immunisation.

Cardiac surgical patients, all of whom had received multiple blood transfusions were tested by this group and all showed leucocyte migration of $75 \%$ or less with $67 \%$ or more of the antigen preparations used. Although transplantation antigens have yet to be demonstrated on the surface of synovial cells, it seems highly probable that they are present and are responsible for migration inhibition of sensitised leucocytes. In our studies when leucocytes came from either RA or control nontransfused males allogeneic responses disappeared.

Seropositive for rheumatoid factor was not necessary for a response to autologous leucocytes. Two of the 3 seronegative patients reacted including one (case 9) who gave the greatest inhibition of the series.

Other attempts to demonstrate cell-mediated immune responses to unique rheumatoid synovial antigens have been for the most part inconclusive. Positive results such as with the leucocyte migration inhibition test ${ }^{2}$ and with blastogenic responses ${ }^{4}$ might have been induced by lymphokines which result from nonspecific reactions rather than a specific response to a synovial antigen. Surface absorbed immunoglobulins may also have been responsible for these reactions. Conflicting but generally negative results have come from an attempt to identify immunospecific lymphocytotoxicity. In one study ${ }^{6} \mathrm{RA}$ lymphocytes were more toxic to synovial cells cultured for short rather than long periods. Person et $a .^{21}$ produced results that strongly suggested that rheumatoid lymphocytes were sensitised to antigens present on rheumatoid synovial cells. However, Ghose et al. ${ }^{22}$ were unable to demonstrate any significant interaction in vitro between cultured synovial cells and autologous lymphocytes or sera.

These studies have used explant cultures of surgically removed synovial tissue entailing various numbers of passages before extracts were made or before the cells were used for cytoxicity assays. Explant cultures produce a fibroblastic cell line certainly derived from the synovial membrane but with some differences. The abnormalities of RA derived cultures compared to non-RA cells persist. ${ }^{23-25}$ The results of Griffiths et al.$^{6}$ showing that RA lymphocytes were more cytotoxic for synovial cells cultured for short rather than long periods indicate that some specificity and hence antigenic expression may be lost with excessive passages. It has been shown that in other cells lines in tissue culture loss of tissue specific antigens ${ }^{26}$ and decreased expression of transplantation antigens ${ }^{27}$ have occurred. There is the risk that older synovialderived cell cultures may be overgrown with the nonsynovial cell type.

In our studies, by comparison with explant cultures in which there is a rapid growth of fibroblasts, multiplication is rare in cells removed from intact joints by trypsinisation. ${ }^{9}$ Although increase in size of cells occurs when they are grown in medium supplemented with human serum, subculturing did not take place, and, because of the short period of 10-21 days of culture, loss of any specific antigen contained in synovial cells could be minimised before the preparation of the synovial extract. The culture period after separation of cells from the RA joint did allow for contaminating synovial fluid, blood cells, and synovial cells apart from synoviocytes, to be washed free while allowing surface antigens stripped from the cell membrane by trypsin to be replaced.

It is known that viral cell surface antigens, for example, are regenerated within 24 hours of trypsi- 
nisation, ${ }^{28}$ and trypsin was not used in the final separation of the cells before preparation of the synovial extract. Also, before the extract was prepared, the cells were cultured in media free of human protein, and immunofluorescence studies showed that effective removal of bound human immunoglobulins had been achieved. All these precautions were taken to ensure that the positive inhibition results with autologous leucocytes could not be due to residual inflammatory mediators or to retained aggregated or native IgG associated with cells. High concentrations of native IgG and heat-aggregated immunoglobulins have been shown to be necessary to produce a positive leucocyte inhibition response, i.e. $250 \mu \mathrm{g} / \mathrm{ml}^{3}{ }^{3}$ This should be compared with the $50 \mu \mathrm{g}$ concentrations used in our experiments, which produced significant inhibition and thus provided further evidence of the specific basis of the reaction.

Ethical considerations prevented tryspinisation of normal or osteoarthritic joints from living donors, and so control cultures originated from cadavers. As such cells were subcultured with a mean of 7 passages before preparation of the synovial extract, there was the potential for multiplication of fibroblasts. However, allogeneic responses were possible with individual leucocyte preparations but not with all donor leucocytes. Some antigenic material (? HLA derived) is clearly retained in these preparations It is unfortunate that as control synovial cells came from cadavers, autologous leucocytes were not available for testing. It is the autologous reaction with RA leucocytes that is the most interesting finding in these experiments.

If blood was taken for a leucocyte inhibition test within a week of the patient receiving a gold injection, there was a significant reduction in leucocyte migration inhibition. It is known from studies in experimental animals that gold inhibits some of the cellular and fluid phases of inflammation and, for example, suppresses the phagocytic activity of both macrophages and neutrophils. ${ }^{29}$ With in-vitro experiments using human lymphocyte responses gold has also been shown to be inhibitory. ${ }^{30}{ }^{31}$ Other antirheumatic drugs including aspirin, indomethacin, naproxen, and D-penicillamine have been tested in similar fashion and can produce inhibition responses at concentrations approaching therapeutic levels. ${ }^{31}$

Corticosteroids are known to affect $\mathrm{T}$ cell function, ${ }^{32}{ }^{33}$ but the only 2 patients in the series who were on corticosteroids were receiving very low doses-a daily intake of prednisolone of $3 \mathrm{mg}$ or $5 \mathrm{mg}$. One of these (case 10) was on 4 antiarthritic drugs when tested initially and failed to react to autologous and several allogeneic extracts. The 4 drugs (pred- nisolone, D-penicillamine, aspirin, and indomethacin) were withdrawn for 48 hours and the tests repeated. Significant inhibition was then shown to beth autologous and one allogeneic extract.

It is possible therefore that drugs may have affected responses, as otherwise no attempt was made to discontinue medication before venesection. Our own evidence with gold and the in-vitro studies of others indicate that depression rather than enhancement of responses might be related to the use of drugs, and therefore drugs could not be responsible for the positive inhibition with autologous extracts demonstrated here.

The nature of the 'rheumatoid' specific antigen(s) has yet to be determined. Preliminary fractionation of synovial extracts indicate that it has a large molecular weight or is membrane bound. Possible explanations are that the substance is a putative antigen acquired from the environment despite the consistently negative attempts directly to demonstrate microbial involvement in RA. Alternatively an infectious agent such as a virus might have induced a cell membrane change recognised by sensitised RA lymphocytes. ${ }^{21}$ Another explanation is that joint destruction may have induced an altered cell component, resulting in an autoimmune reaction, with sensitised lymphocytes as well as autoantibodies being produced. ${ }^{6} 34$ A further alternative is that the reaction could be due to an abnormality of the immune system with loss of immunoregulatory control generating autoreactive products. ${ }^{1}$ There is as yet no decisive experimental evidence indicating participation of an infective agent, and the other alternatives remain speculative. Studies demonstrating that material cross-reacting like carcinoembryonic antigen (CEA) could be extracted from RA synovial membrane ${ }^{35}$ require clarification in the light of our experiments indicating that 9 out of 10 RA patients showed reactions to their own synovial extracts. It is probable but not certain that the antigen suggested by these leucocyte migration inhibition tests is not identical in each extract, as patients were tested against at least one RA preparation and not all showed cross-reactivity.

This work was supported by a grant from the National Health and Medical Research Council of Australia. The authors are grateful to Dr K. Boyden for isolation of the rheumatoid cells and Dr B. J. Clarris and Dr J. R. E. Fraser for the control cells. Essential advice and encouragement was received from Dr J. R. E. Fraser, Dr B. J. Clarris, and Dr B. D. Tait.

\section{References}

1 Marmion B P. Infection, auto-immunity and rheumatoid arthritis. Clin Rheum Dis 1978; 4: 565-86. 
2 Bacon P A, Cracchiolo A, Bluestone R, Goldberg L S. Cell-mediated immunity to synovial antigens in rheumatoid arthritis. Lancet 1973; 2: 699-702.

3 Bacon P A, Weisbart R H, Cracchiolo A, Bluestone R, Goldberg L S. Cellular immunity to synovial extracts and to IgG in rheumatoid arthritis. In: Dumond D C, ed. Infection and Immunology in the Rheumatic Diseases. London: Blackwell Scientific Publications, 1976: 479-82.

4 Kinsella T D. Transformation of human lymphocytes in vitro by autologous and allogeneic rheumatoid synovial fluids. Ann Rheum Dis 1976; 35: 8-13.

5 Person D A, Sharp J T. The etiology of rheumatoid arthritis. Bull Rheum Dis 1976; 27 : 888-93.

6 Griffiths M M, Smith C B, Ward J R, Klauber M R. Cytotoxic activity of rheumatoid and normal lymphocytes against allogeneic and autologous synovial cells in vitro. J Clin Invest 1976; 58: 613-33.

7 Maini R N. Immunology of the rheumatic diseasesaspects of autoimmunity. In: Current Topics in Immuno$\log y$ 7. London: Arnold: 1977: 33-5.

8 Fraser J R E, Catt K J. Human synovial-cell culture. Use of a new method in a study of rheumatoid arthritis. Lancet 1961; 2: 1437-9.

- Clarris B J, Fraser J R E, Moran C S, Muirden K D. Rheumatoid synovial cells from intact joints. Morphology, growth and polykaryocytosis. Ann Rheum Dis 1977; 36: 293-301.

10 Clarris B J, Fraser J R E. Relationship between chromosomal changes and alterations in the behaviour of a strain of human synovial cells during its life history in vitro. Ann Rheum Dis 1968; 27: 597-603

11 Marsh J M, Maini R N, Wiebkin O W, Dumond D C. Rheumatoid and normal synovial tissue in long term culture. Evidence of cell heterogeneity and an approach to quantitation of populations and the effect of passage. J Rheumatol 1978; 5: 148-61.

12 Sany J, Clot J. Cell-mediated immunity to undenatured IgG in rheumatoid arthritis. In: Dumond $\mathrm{D} C$, ed. Infection and Immunology in the Rheumatic Diseases. London: Blackwell Scientific Publications, 1976: 471-4.

13 Eibl M M, Sitko C. MIF production of lymphocytes from patients with rheumatoid arthritis with antigen - antibody complexes. Ann Rheum Dis 1975; 34: 117-21.

14 Eibl M M. Cell-mediated immunity to immune-complexed immunoglobulin in rheumatoid arthritis. In: Dumond $\mathrm{D} \mathrm{C}$, ed. Infection and Immunology in the Rheumatic Diseases. London: Blackwell Scientific Publications, 1976: 475-7.

15 Soborg M, Bendixen G. Human lymphocyte migration as a parameter of hypersensitivity. Acta Med Scand 1967; 181 : $247-56$

16 Soborg M. In vitro migration of peripheral human leucocytes in cellular hypersensitivity. Acta Med Scand 1968; 184: 135-9.

17 Falk R E, Thornsby E, Möller E, Möller G. In vitro assay of cell-mediated immunity: the inhibition of migration of sensitised human lymphocytes by HL-A antigens. Clin Exp Immunol. 1970; 6: 445-55.

18 Falk R E, Guttmann R D, Falk J A, et al. Assessment of the cellular-immune response to $\mathrm{HL}-\mathrm{A}$ antigens in human renal allograft recipients. Clin Exp Immunol 1973 ; 14 : 47-56.
19 Tait B D, d'Apice A J F, Morris P J. Maternal cell mediated immunity to foetal transplantation antigens. Tissue Antigens 1974; 4: 586-94.

20 Tait B D, Barrie J U, Johnston I, Morris P J. Cellular immunity to lymphocyte antigens in human infertility. Fertil Steril 1976; 27: 389-96.

21 Person D A, Sharp J T, Lidsky M D. The cytotoxicity of leukocytes and lymphocytes from patients with rheumatoid arthritis for synovial cells. J Clin Invest 1976; 58: $690-8$.

22 Ghose T, Woodbury J F, Hansell M M. Interaction in vitro between synovial cells and autologous lymphocytes and sera from arthritis patients. J Clin Pathol 1975; 28: $550-8$.

23 Castor C W. Connective tissue activation. II. Abnormalities of cultured rheumatoid synovial cells. Arthritis Rheum 1971; 14: 55-66.

24 Smith C. Properties of synovial cells in culture. $J$ Exp Med 1971; 134: 3065-125.

25 Wynne-Roberts C R, Castor C W. Ultrastructural comparison of rheumatoid and non-rheumatoid synovial fibroblasts grown in tissue culture. Arthritis Rheum 1972; 15: 65-83.

26 Jonsson J, Fagraeus A, Sundquist K G. Stimulation of organ specific and non-organ specific antigens on the surface of thyroid cells by phytohaemagglutinin $P$. Scand J Immunol 1973; 2: 239-50.

27 Sasportes M, Dehay C, Fellous M. Variations of the expression of HL-A antigens on human diploid fibroblasts in vitro. Nature 1971; 233: 332-4.

28 Perrin L H, Joseph B S, Cooper N R, Oldstone M B A. Mechanism of injury of virus-infected cells by antiviralc antibody and complement: Participation of IgG, F(ab $\left.{ }^{1}\right)_{2}$, and the alternative complement pathway. $J$ Exp Med 1976; 143: 1027-41.

29 Vernon-Roberts B, Jessop J D, Doré J. Effects of gold salts and prednisolone on inflammatory cells. II. Suppression of inflammation and phagocytosis in the rat. Ann Rheum Dis 1973; 32: 301-7.

30 Lipsky P E, Ziff, M. Inhibition of antigen and mitogen induced human lymphocyte proliferation by gold compounds. J Clin Invest 1977 ; 59: 455-66.

31 Panush R. Effects of certain antirheumatic drugs on normal human peripheral blood lymphocytes. Inhibition of mitogen- and antigen-stimulated incorporation of tritiated thymidine. Arthritis Rheum 1976; 19: 907-17.

32 Fauci A S, Dale D C. The effect of in vitro hydrocortisone on subpopulations of human lymphocytes. J Clin Invest 1974; 53: 240-6.

33 Gottlieb A B, Lahita R G, Chiorazzi N, Kunkel H G. Immune function in systemic lupus erythematosus. Impairment of in vitro $\mathrm{T}$-cell proliferation and in vivo antibody response to exogenous antigen. $J$ Clin Invest $1979 ; 63$ : 885-92.

34 Glynn L E. Pathology, pathogenesis and etiology of rheumatoid arthritis. Ann Rheum Dis 1972; 31: 412-20.

35 Unger A, Panayi G S, Tidman N H. Comparative study of carcino-embryonic antigen in rheumatoid synovium, tumour and normal adult lung. Ann Rheum Dis 1977; 36: 66-70. 